\title{
IBNU RUSYD DAN KONTRIBUSI PEMIKIRANNYA TERHADAP PERKEMBANGAN ILMU FIQIH
}

\author{
Mohamad Thoyyib Madani \\ STAI Nazhatut Thullab Sampang \\ E-mail: oyib_madani@yahoo.co.id
}

\begin{abstract}
Abstrak :
Tulisan mengkaji tentang pemikiran Ibnu Rusyd di bidang pendidikan, terutama fiqh. Ibnu Rusyd berpikir tentang yurisprudensi pendidikan dapat ditemukan, dengan pemikiran filosofis yang mendalam, sekitar dua bagian ilmu, yaitu metode konsep (tasawwur), dan verifikasi (tasdiq). Metode tasdiq, mengelompokkan manusia, sesuai dengan kemampuan berfikirnya, menjadi tiga kelompok, yaitu ahl al-khitab, ahl al-jadal, dan ahl alburhan. klasifikasi, menyebabkan metode penyampaian pendidikan fiqh berbeda, disesuaikan dengan kemampuan berpikir manusia, bahwa dalam pembahasan fikih, dibagi menjadi tiga kelompok, yaitu biasa, muqtasid, dan mujtahid. Awam identik ahl al-khitab, muqtasid identik ahl al-jadal, dan mujtahid identik dengan ahl alburhan.
\end{abstract}

Kata kunci: Pemikiran Ibnu Rusyd, Ilmu Fiqih.

\begin{abstract}
:
This article studies about the thought of Ibn Rusyd in education, especially fiqh. Ibn Rusyd thinking about education jurisprudence can be found, with deep philosophical thought, about two parts of science, namely the method of concept (tasawwur), and verification (tasdiq). Tasdiq methods, classifying humans, according to the ability berfikirnya, into three groups, namely al-khitab ahl, ahl aljadal, and ahl al-burhan. the classification, causes fiqh education delivery methods are different, customizable, with the ability to think man, that in the discussion of jurisprudence, divided into three groups, namely ordinary, muqtasid, and mujtahid. Layman identical, the ahl al-khitab; muqtasid identical, the ahl al-jadal, and mujtahid synonymous with ahl al-burhan.
\end{abstract}

Keywords: Thought of Ibn Rusyd, Fiqh 


\section{Pendahuluan}

Fiqih adalah salah satu bidang ilmu dalam syariat Islam, yang secara khusus membahas persoalan hukum, yang mengatur berbagai aspek kehidupan manusia, baik kehidupan pribadi, bermasyarakat maupun hubungan manusia, dengan Tuhannya. ${ }^{1}$ Beberapa ulama fiqih, seperti Imam Abu Hanifah mendefinisikan fiqih sebagai pengetahuan seorang muslim, tentang kewajiban, dan haknya sebagai hamba Allah. ${ }^{2}$

Fiqih adalah salah satu cabang ilmu Agama Islam, yang diarahkan untuk menyiapkan peserta didik, untuk mengenal, memahami, menghayati, dan mengamalkan hukum Islam, melalui kegiatan bimbingan, latihan, penggunaan pengalaman, dan pembiasaan. Adapun tujuan, yang akan dicapai, dari pendidikan fiqih, adalah membekali peserta didik, agar dapat mengetahui, dan memahami pokok-pokok hukum Islam, secara terperinci, dan menyeluruh. Pengetahuan, dan pemahaman tersebut, diharapkan menjadi pedoman hidup, dan kehidupan peserta didik secara pribadi maupun sosial.

Di samping itu, peserta didik diharapkan dapat melaksanakan, dan mengamalkan ketentuan hukum Islam, secara benar. Pengamalan tersebut, diharapkan dapat menumbuhkan ketaatan, dalam menjalankan hukum Islam, yang dilaksanakan secara disiplin, dan rasa tanggung jawab pribadi yang tinggi, dalam kehidupan pribadi para peserta didik, dan kehidupan sosialnya.

Pendidikan fiqih mempunyai kedudukan, yang urgen, dalam kerangka kehidupan beragama peserta didik, karena dengan mempelajari fiqih, peserta didik dapat memiliki pengetahuan, dan pemahaman, tentang bagaimana cara beribadah yang baik, apa yang diperbolehkan, dan apa pula yang dilarang saat melakukan ibadah. Disamping itu, dalam pembelajaran fiqih, peserta didik juga diharapkan dapat memiliki pemahaman tentang tata cara berhubungan dengan orang lain dalam kehidupan sosial. Oleh karena itu, berbicara pendidikan agama Islam, baik makna maupun tujuannya haruslah mengacu pada penanaman nilai-nilai Islam dan tidak dibenarkan melupakan etika sosial atau moralitas sosial. Penanaman nilai-nilai ini juga dalam rangka menuai keberhasilan

\footnotetext{
${ }^{1}$ Muhammad Yusuf Musa, al-Madkhal li Dirasat al-Fiqh al-Islami, (Kairo: Dar alKutub al-'Araby, 1953), 11.

2 Abdul Aziz Dahlan (ed.) et. al., Ensiklopedi Hukum Islam, Vol. 4 (Jakarta: Ichtiar Baru Van Hoeve, 1996), 590.
} 
hidup (hasanah) di dunia bagi anak-anak didik yang kemudian akan mampu membuahkan kebaikan (hasanah) di akhirat kelak. ${ }^{3}$

Konsep pendidikan, dalam perkembangannya, menjadi bahan pemikiran tokoh pendidikan, mulai era klasik sampai kontemporer sekarang ini. Tokoh-tokoh yang memberikan sumbangsih di bidang pendidikan, antara lain Abu Yusuf an-Namry dalam kitabnya 'Adab al-Mujalasah', Abu Zakariya an-Nawawi dalam kitabnya 'at-Tibyan', Abdullah Nasih Ulwan dalam kitabnya Tarbiyyat al-Aulad fi alIslam dan Ibnu Rusyd, di dalam beberapa kitabnya. Metode yang digunakan, dalam pembelajaran fiqih, pada awalnya adalah metode dialog, dalam sistem halaqah, yaitu syaikh atau guru dikelilingi oleh murid-muridnya. Di dalam halaqah tersebut, seorang guru mentransfer pengetahuannya, dan berdiskusi dengan muridmuridnya mengenai persoalan-persoalan hukum yang dihadapi.

Proses dialog ini, kemudian menumbuhkan ijtihad di kalangan para faqih. Para ahli hukum kemudian mengumpulkan hasil ijtihadnya, dan membukukannya menjadi kitab-kitab fiqih. Kitab-kitab fiqih tersebut menjadi materi pokok yang digunakan dalam pambelajaran fiqih.

Pembukuan kitab fiqih dimulai awal abad ke-2 H. Pada awalnya, penyusunan permasalahan fiqih belum sistematis. Hal ini dikarenakan persoalan yang dicantumkan dalam kitab fiqih, adalah persoalan yang dipertanyakan masyarakat, atau persoalan yang muncul di tengah masyarakat. Kadang-kadang kitab fiqih disusun oleh murid seorang Imam, berdasarkan urutan fatwa yang dikeluarkan Imam tersebut. Umpamanya Imam Muhammad bin Hasan as-Syaibani menyusun kitab fiqih Zahir ar-Riwayah, yang merupakan kumpulan hasil ijtihad Imam Abu Hanifah, gurunya. Di samping itu, ada uraian fiqih secara luas, yang dikemukakan seorang ulama, ketika ia membahas hadits, seperti al-Muwattha' oleh Imam Malik bin Anas. Kitab tersebut adalah kitab hadits, tetapi disusun sesuai dengan urutan permasalahan fiqih, sehingga dianggap sebabagai kitab fiqih. ${ }^{4}$

Kitab fiqih, yang disusun secara sistematis, baru muncul pada awal abad ke-3 H. Seperti, al-Mudawwanah al-Kubra. Kitab ini merupakan kitab fiqih standar, dalam madzhab Maliki, dan al-Umm yang disusun oleh Imam Syafi'i. Dalam perkembangan selanjutnya, yaitu setelah bermunculannya madzhab-madzhab fiqih, kitab fiqih

\footnotetext{
${ }^{3}$ Moh Wardi, "Penerapan Nilai Pendidikan Agama Islam Dalam Perubahan Sosial Remaja”, TADRIS: Jurnal Pendidikan Islam STAIN Pamekasan Vol. 7 No. 1 2013, 35.

${ }^{4}$ Abdul Aziz Dahlan (ed.) et. al., Ensiklopedi ..., 620.
} 
disusun, sesuai dengan madzhab-madzhab fiqih, yang ada, seperti madzhab Hanafi, Maliki, Syafi'i, Hambali, ad-Dzahiri, Ja'fari, dan sebagainya. Ada juga kitab fiqih, yang sama sekali, tidak terikat, dengan madzhab tertentu. ${ }^{5}$

Dilihat dari segi isinya, kitab-kitab fiqih, yang ditulis oleh ulama fiqih sejak zaman klasik sampai sekarang, bisa dikelompokkan, menjadi beberapa kelompok, yaitu:

Pertama, kitab fiqih lengkap, yakni kitab fiqih, yang membahas seluruh permasalahan fiqih, mencakup permasalahan ibadah, muamalah, al-ahwal as-syakhshiyyah, pidana, persoalan peradilan, dengan segala perangkatnya, politik, jihad, perang dan damai. Kitab fiqih lengkap, ada kalanya disusun sesuai, dengan pendapat madzhab tertentu, tanpa membandingkannya, dengan pendapat madzhab lain, dan ada kalanya, juga membahas berbagai pendapat madzhab fiqih, baik sebagai penjelasan, atau sebagai perbandingan. Di samping itu, ada juga kitab fiqih, yang sebenarnya membahas kaidah fiqih, tetapi pembahasannya disusun berdasarkan sistematika fiqih.

Kedua, kitab fiqih tematis, yakni kitab fiqih yang hanya membahas topik tertentu, seperti masalah kharaj, harta, peradilan, pemerintahan, perdata dan pidana. Di zaman klasik, kitab fiqih tematis ini belum banyak ditulis ulama' fiqih. Pada zaman sekarang, banyak kitab fiqih bermunculan, karena pembidangan, dalam ilmu fiqih semakin berkembang.

Ketiga, kitab fiqih berbentuk kumpulan fatwa, yaitu kitab fiqih yang disusun berdasarkan hasil fatwa ulama atau sekelompok ulama tertentu.

Pada zaman klasik, kitab-kitab fiqih hanya ditulis, sesuai dengan pendapat madzhab tertentu saja. Kitab tersebut hanya menyebutkan pendapat madzhab tertentu, dengan argumentasi, yang menguatkan pendapat madzhabnya sendiri. Terkadang juga, di dalam kitab tersebut, disebutkan pendapat, dari madzhab lain. Akan tetapi pendapat madzhab lain tersebut, dilemahkan, dengan argumentasi madzhab, yang dianut oleh penulisnya. Hal ini terus berlangsung sekian lama sehingga polarisasi madzhab-madzhab fiqih semakin lebar, dan fanatisme madzhab semakin kental. Barulah pada pertengahan abad ke-12 $\mathrm{H}$. muncul terobosan baru, dalam pembelajaran fiqih, yaitu dengan disusunnya kitab Bidayat al-Mujtahid wa Nihayat al-Muqtasid oleh Muhammad bin Ahmad bin Muhammad Ibnu Rusyd.

5 Ibid. 


\section{Definisi Fiqih}

Secara etimologi, kata fiqih berasal dari kata merupakan bentuk masdar dari kata kerja فَقِقَََفْقَهُهُ merupakan sinonim dari فَفْ

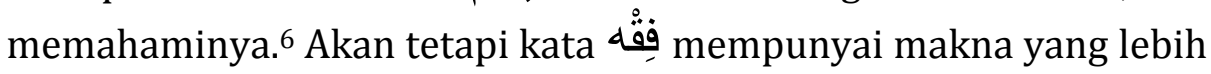
khusus daripada فَ فَ (paham), karena kata fiqih berarti memahami maksud pembicaraan orang yang berbicara, yang tidak sekedar mengerti lafadznya saja. ${ }^{7}$ Fiqih berarti pemahaman yang mendalam, yang membutuhkan pengerahan potensi akal. ${ }^{8} \mathrm{Al}-$ Qur'an beberapa kali menyebutkan kata fiqih di dalam beberapa surat, yaitu antara lain di dalam Surat Taha:

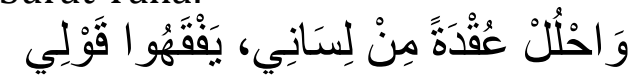

"Dan lepaskanlah kekakuan dari lidahku, supaya mereka memahami perkataanku."

dan Surat al-Tawbah:

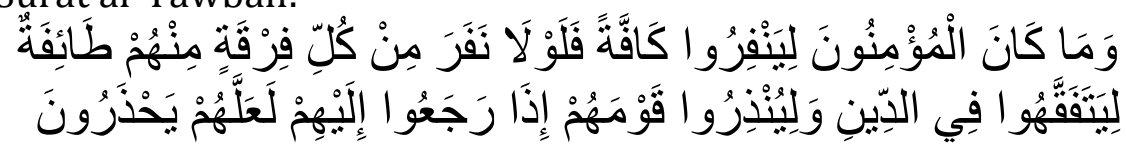

"Tidak sepatutnya bagi mukminin itu pergi semuanya (ke medan perang). Mengapa tidak pergi dari tiap-tiap golongan di antara mereka beberapa orang untuk memperdalam pengetahuan mereka tentang agama dan untuk memberi peringatan kepada kaumnya apabila mereka telah kembali kepadanya, supaya mereka itu dapat menjaga dirinya." 10

dan Surat al-A'raf:

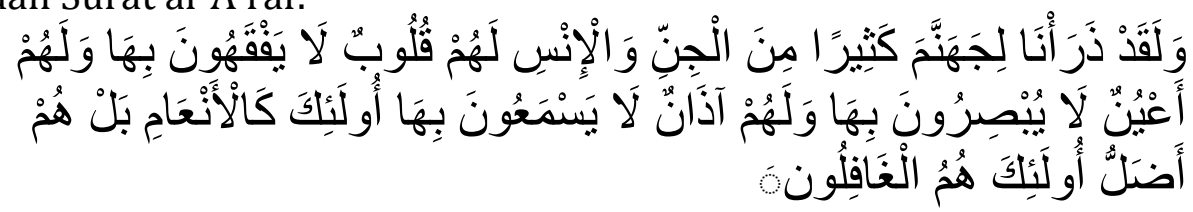

Dan sesungguhnya Kami jadikan untuk (isi neraka Jahannam) kebanyakan dari jin dan manusia, mereka mempunyai hati, tetapi

\footnotetext{
${ }^{6}$ Muhammad bin Mukarram bin 'Ali al-Ansari, Lisan al-'Arab (Bairut: Dar Sadir, 1414 H.), vol. 13, 522.

7 Ibn al-Qayyim al-Jauziyyah, I'lam al-Muwaqqi'in 'An Rabb al-'Alamin (Bairut: Dar al-Kutub al-'Ilmiyyah, 1991), vol. 1, 167.

8 Nasrun Harun, Ushul Fiqh (Jakarta: Logos Wacana Ilmu, 1997), vol. 1, 2.

${ }^{9}$ QS. Taha: 27-28.

${ }^{10}$ QS. al-Tawbah: 122.
} 
tidak dipergunakannya untuk memahami (ayat-ayat Allah) dan mereka mempunyai mata (tetapi) tidak dipergunakannya untuk melihat (tanda-tanda kekuasaan Allah), dan mereka mempunyai telinga (tetapi) tidak dipergunakannya untuk mendengar (ayat-ayat Allah). Mereka itu sebagai binatang ternak, bahkan mereka lebih sesat lagi. Mereka itulah orang-orang yang lalai. ${ }^{11}$

Dan Surat al-Isra':

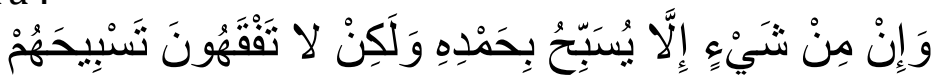

Dan tak ada suatupun melainkan bertasbih dengan memuji-Nya, tetapi kamu sekalian tidak mengerti tasbih mereka. ${ }^{12}$

Menurut Imam Abu Hanifah, fiqih adalah pengetahuan seseorang, tentang sesuatu yang diperbolehkan baginya, dan sesuatu yang tidak diperbolehkan. ${ }^{13}$ Sedangkan menurut ulama' madzhab Maliki, Syafi'i, dan Hanbali, fiqih adalah mengetahui hukum-hukum syar'i dari amal perbuatan, yang digali dari dalildalilnya, yang terperinci. ${ }^{14}$ Perbedaan definisi fiqih tersebut, dikarenakan di zaman Nabi, sahabat, tabi'in, sampai masanya Imam Abu Hanifah, Istilah fiqih belum digunakan untuk pengertian hukum secara khusus, akan tetapi mempunyai pengertian yang luas, mencakup semua dimensi agama, seperti akidah, hukum, akhlaq, tasawwuf. Saat itu, fiqih dipahami sebagai ilmu tentang agama yang akan mengantarkan manusia pada kebaikan, dan kemuliaan. ${ }^{15}$

Menurut al-'Amidi, fiqih adalah mengetahui sekumpulan hukum syar'i, yang bersifat cabang, yang diperoleh melalui penelitian (nazar) dan pencarian dalil (istidlal). ${ }^{16}$ Akan tetapi alMunyawi menyatakan bahwa fiqih itu bukan sekedar ilmu tentang

${ }^{11}$ QS. al-A'raf: 179.

12 QS. al-Isra' : 44.

13 Badr al-din Muhammad bin Abd Allah al-Zarkashi, al-Bahr al-Muhit fi Usul alFiqh (Bairut: Dar al-Kutub, 1994), vol. 1, 36.

${ }^{14}$ Hasan bin 'Umar al- Sinawani, al-Asl al-Jami' li Idhah al-Durar al-Manzumah fi Suluki Jam' al-Jawami' (Tunis: Matba'ah al-Nahdhah, 1928), vol. 1, 6; Wahbah al-Zuhayli, Usul al-Fiqh al-Islami (Damaskus: Dar al-Fikr, 1986), 19; Bakr bin 'Abd Allah Abu Zayd, al-Madkhal al-Mufassal li Madhhab al-Imam Ahmad wa Takhrijat al-Ashab (Jiddah: Dar al-'Asimah, 1417 H.), vol. 1, 44.

15 Mun'im A. Sirry, Sejarah Fikih Islam (Surabaya: Risalah Gusti, 1996), 10.

16 'Ali bin Abi 'Ali al-Amidi, al-Ihkam fi Usul al-Ahkam (Bairut: al-Maktab alIslami, tt.), vol. 1, 6. 
hukum syar'i yang diperoleh dari proses istidlal, tapi hukum itu sendiri, disebut fiqih. ${ }^{17}$

Fiqih pada hakikatnya adalah pendidikan agama dan manajemen syar'i, yang diatur demi kemaslahatan diri seorang hamba, baik itu kemaslahatan di akhirat, seperti yang diatur di dalam bab ibadah, maupun kemaslahatan dunia, seperti yang diatur di dalam bab jual beli, perkawinan, jinayah, dan sebagainya, yang demikian tersebut merupakan tujuan utama diutusnya para Rasul, yaitu mengajarkan manusia tentang hukum-hukum perbuatan, yang kemudian dilanjutkan dengan mengajari mereka tentang ketuhanan, malaikat, kitab-kitab, para utusan, dan seterusnya. ${ }^{18}$

Objek kajian fiqih adalah perbuatan mukallaf, yang telah ditetapkan hukum syar'inya. ${ }^{19}$ Perbuatan tersebut ada kalanya terkait dengan urusan akhirat, dan ada kalanya terkait dengan urusan dunia. Perbuatan yang terkait dengan urusan akhirat adalah ibadah, sedangkan perbuatan yang terkait dengan urusan dunia itu bisa berkaitan dengan kelestarian hidup manusia, dalam segmen pribadi (shakhs), segmen keluarga (manzili), dan segmen peradaban (madani). Perbuatan yang terkait dengan kelestarian hidup manusia, dalam segmen pribadi, diatur di dalam bab muamalah, kelestarian manusia, dalam segmen keluarga, diatur di dalam bab pernikahan, kelestarian manusia, dalam segmen peradaban, diatur di dalam bab jinayah. ${ }^{20}$

Pendidikan adalah upaya mempersiapkan individu, untuk mencapai kehidupan yang lebih baik, di dalam kehidupan pribadi, dan bermasyarakat, kemudian fiqih adalah mengetahui dan memahami hukum Islam, beserta dalil-dalilnya secara terperinci, maka pendidikan fiqih adalah upaya mempersiapkan individu, untuk mengetahui dan memahami hukum Islam, beserta dalildalilnya secara terperinci.

Pendidikan fiqih merupakan salah satu komponen dari pendidikan agama Islam, disamping pendidikan akidah, pendidikan akhlak, sejarah, dan sebagainya. Jika pendidikan akidah membahas

\footnotetext{
17 Mahmud bin Muhammad Abu al-Munzir al-Munyawi, al-Mu'tasar min Sharh Mukhtasar al-Usul min 'Ilm al-Usul (Mesir: al-Maktabah al-Shamilah, 2010), 7.

18 Shihab al-Din Mahmud bin Ahmad al-Zunjani, Takhrij al-Furu' 'ala al-Usul (Bairut: Muassasah al-Risalah, 1398 H), 33.

19 'Abd al-Wahhab Khallaf, 'Ilm Usul al-Fiqh (Kairo: Maktabah al-Da'wah, tt.), 12.

20 Sa'ad al-Din Mas'ud bin 'Umar al-Taftazani, Sharh al-Talwih 'Ala al-Tawdhih (Mesir: Maktabah Sabih, tt.), vol. 2, 288-289.
} 
tentang keyakinan, dan pendidikan akhlaq membahas tentang moral, maka pendidikan fiqih membahas tentang hukum.

\section{Biografi Ibnu Rusyd}

Nama lengkap Ibnu Rusyd adalah Abu al-Walid Muhammad bin Ahmad bin Muhammad bin Ahmad bin Rusyd al-Qurtubi alandalusi. Dia biasa dipanggil dengan sebutan Abu al-Walid, Ibnu Rusyd atau Ibnu Rusyd al-Hafid. Penambahan gelar al-Hafid adalah untuk membedakan Ibnu Rusyd dari kakeknya, yang sama-sama bernama Muhammad bin Ahmad, biasa dipanggil dengan sebutan Ibnu Rusyd, dan memiliki nama kunyah ${ }^{21}$ Abu al-Walid. ${ }^{22}$ Oleh orang Perancis, Ibnu Rusyd dipanggil dengan sebutan Averroes, sehingga di dunia barat, dia populer dengan sebutan Averroes. ${ }^{23}$

Ibnu Rusyd dilahirkan di kota Qurtubah, atau Cordova, salah satu kota di Andalusia, pada tahun 1126 M./ 520 H., yaitu satu bulan sebelum kakeknya, Muhammad bin Ahmad Ibnu Rusyd alFaqih, meninggal. ${ }^{24}$ Ibnu Rusyd berasal dari keluarga ilmuwan. Ayah dan kakeknya adalah pecinta ilmu, dan merupakan ulama' yang sangat disegani di Andalusia (Andalusia) pada masanya. Ayahnya, Abu al-Qasim Ahmad bin Muhammad (1083-1169 M./ 487-563 H.), adalah seorang ahli fiqih dan pernah menjadi hakim di Cordova, sementara kakeknya, Muhammad bin Ahmad Ibnu Rusyd al-Faqih (1058-1126 M./ 450-520 H.), adalah ahli fiqih madhhab Maliki, dan Imam masjid Cordova, serta pernah menjabat sebagai hakim agung di Andalus. ${ }^{25}$ Jadi, tidak mengherankan jika derajat ilmuwan mengalir dalam tubuh Ibn Rusyd, sehingga ia pun tumbuh menjadi seorang ilmuwan di segala bidang, yakni sebagai ahli hukum Islam (faqih), dokter, ahli matematika, astronom, filosof, dan sebagainya. Sebagaimana ayah dan kakeknya, Ibn Rusyd juga pernah menjadi hakim dan qadhi al-qudhat di andalusia.

\section{Karya-Karya Ibnu Rusyd}

21 Kunyah adalah nama julukan dengan awal kata-kata abu, atau umm. Lihat Ahmad Warson Munawwir, Kamus al-Munawwir (Yogyakarta: UPBIK PP alMunawwir, tt.), 1326.

22 Khayr al-din bin Mahmud al-Zarkali al-Dimashqi, al-A'lam li al-Zarkali (Damaskus: Dar al-'Ilm li al-Malayin, 2002), vol. 5, 318.

23 Ibid.

24 Shamsh al-Din Abu Abd Allah Muhammad bin Ahmad al-Dhahabi, Tarikh alIslam wa Wafiyyat al-Mashahir wa al-A'lam (Bairut: Dar al-Kitab al-'Arabi, 1993), vol. 42, 196.

25 Abbas Mahmud al-'Aqqad, Ibn Rushd (Mesir: Dar al-Ma'arif, tt.), 18. 
Ibnu Rusyd merupakan ilmuwan yang sangat peduli, pada ilmu pengetahuan. Seumur hidupnya, dia dedikasikan untuk kegiatan keilmuan, sampai-sampai, ia tidak pernah absen, dari kegiatan belajar, setiap malam, kecuali dua malam, yaitu ketika ayahnya meninggal dunia, dan malam pertama pernikahannya. ${ }^{26}$

Buku-buku, yang dikarang oleh Ibnu Rusyd banyak sekali, dari berbagai disiplin ilmu: Filsafat, Kedokteran, Politik, Fiqih, dan masalah-masalah agama. Sebagian karya-karyanya banyak yang hilang dan ada juga yang dibakar. ${ }^{27}$ Makanya para ahli sejarah berbeda pendapat akan jumlah buku-buku hasil karyanya.

Menurut Renan, karya Ibnu Rusyd cukup banyak, mencapai sekitar 78 karya, yang ditulis dalam berbagai bidang. ${ }^{28}$ Ibnu Farhun menyatakan bahwa Ibnu Rusyd meninggalkan, tidak kurang 60 karya, ${ }^{29}$ al-Zarkali menyatakan, bahwa Ibnu Rusyd meninggalkan, tidak kurang 50 karya, $^{30}$ dan al-Dhahabi menyatakan, bahwa keseluruhan karya Ibnu Rusyd, adalah, tidak kurang dari sepuluh ribu lembar, dari berbagai disiplin ilmu: filsafat, kedokteran, politik, fiqih, dan masalah-masalah agama. ${ }^{31}$

Kebesaran dan kejeniusan Ibnu Rusyd tampak pada karyakaryanya. Dalam berbagai karyanya ia selalu membagi pembahasannya ke dalam tiga bentuk, yaitu komentar, kritik, dan pendapat. ${ }^{32}$ Ia adalah seorang komentator, sekaligus kritikus ulung. Ulasannya, terhadap karya-karya filsuf besar, terdahulu, banyak sekali, antara lain ulasannya terhadap karya-karya Aristoteles.

Secara resmi, Ibn Rusyd memang diminta oleh Amir Abu Ya'qub Yusuf, untuk menulis komentar, atas berbagai karya Aristoteles, di mana, untuk setiap buku, dia membuat tiga kategori komentar, yaitu ringkasan (jami'), komentar singkat (talkhis), dan komentar detail (sharh atau tafsir). Yang terakhir disiapkan untuk mahasiswa tingkat tinggi.

Dalam ulasannya itu, ia tidak semata-mata memberi komentar, terhadap filsafat Aristoteles, tetapi juga menambahkan pandangan-pandangan filosofisnya sendiri, suatu hal yang belum pernah dilakukan, oleh filsuf semasa maupun, sebelumnya. Kritik, dan komentarnya itulah yang mengantarkannya, menjadi terkenal,

\footnotetext{
${ }^{26}$ Kamil Muhammad, Ibnu Rushd, ........., 25.

27 Muhammad bin Ahmad al-Dhahabi, Tarikh al-Islam..., vol 42, 224.

28 Mahmud Iqbal, Ibnu Rushd dan Averroisme...., 26.

29 Ibnu Farhun Burhan al-Din al-Ya'mari, al-Dibaj al-Muhadhdhab fi Ma'rifat

A'yan 'Ulama' al-Madhhab (Beirut: Dar al-Kutub al-Ilmiyyah, tt.), 285.

30 Al-Zarkali al-Dimashqi, al-A'lam ..., vol. 5, 318

31 Muhammad bin Ahmad al-Dhahabi, Tarikh al-Islam..., vol. 42, 198.

32 'Abd al-Rahman Badawi, al-Falsafah wa al-Falasifah...., 117.
} 
di Eropa. Ulasan-ulasannya, terhadap filsafat Aristoteles, berpengaruh besar, pada kalangan ilmuwan Eropa, sehingga muncul, di sana suatu aliran, yang dinisbatkan kepada namanya, Avereroisme. Selain itu, ia juga banyak mengomentari karya-karya filsuf muslim pendahulunya, seperti al-Farabi, Ibnu Sina, Ibnu Bajjah, dan al-Ghazali. Komentar-komentarnya itu banyak diterjemahkan orang ke dalam bahasa Latin dan Ibrani. ${ }^{33}$

Di antara karya besar pernah dihasilkan Ibnu Rusyd ialah Bidayat al-Mujtahid wa Nihayat al-Muqtasid, al-Hayawan, alKulliyyat, Sharh Urjuzah Ibnu Sina, Jawami' Kutub Aristu, Talkhis alIlahiyyat, Talkhis Ma Ba'da al-Tabi"ah, Sharh al-Sama' wa al-'Alam, Talkhis al-Ustuqsat, Talkhis al-Mazaj, al-Qawiyy, al-'Ilal, al-Ta'arruf, al-Himyat, Hilat al-Bur'i, Talkhis al-Sima' al-Tabi'i, Tahafut alTahafut, Minhaj al-Adillah, Fasl al-Maqal fi Ma Bain al-Shari'ah wa al-Hikmah min al-Ittisal, Sharh al-Qiyas, Maqalah fi al-'Aql, Maqalah fi al-Qiyas, Al-Fahs fi Amr al-'Aql, Al-Fahs fi 'an Masa'il Waqa'at fi alUluhiyyat, Min al-Shifa', Mas'alah fi al-Zaman, Maqalah fi $\mathrm{Ma}$ Ya'taqiduh al-Musha'un wa al-Mutakallimun min Ahli MillaMillatina, Kayfiyyat Wujud al-'Alam, Mutaqarib al-Ma'na, Maqalah fi Nazr Abi Nasr al-Farabi, dan lain-lain. ${ }^{34}$ Kebanyakan karya Ibnu Rusyd tersebut sudah hilang, sebagian sudah dialih-bahasakan ke dalam Bahasa Latin atau Ibrani, dan bisa ditemukan di beberapa perpustakaan, di eropa. ${ }^{35}$

\section{Wafatnya Ibnu Rusyd}

Setelah al-Mansur kembali ke ibukota Dinasti Muwahhidun, Marakesh, datanglah sekelompok orang, kepadanya, dan membuktikan, bahwa Ibnu Rusyd tidak bersalah, dalam hal ini. Maka khalifah pun memanggil kembali Ibnu dari pengasingan, dan merehabilitasi kehormatannya. Untuk beberapa lama, Ibnu Rusyd menetap di Marakesh, sebagai orang kepercayaan khalifah, sampai dia meninggal. ${ }^{36}$

Ibnu Rusyd meninggal dunia, di Marakesh, pada hari Kamis, 9 Safar 595 H., atau bertepatan dengan tanggal 10 Desember 1198 M., ${ }^{37}$ ketika berumur 72 tahun, menurut perhitungan Masehi, dan 75 tahun, menurut perhitungan Hijrah.. Jasadnya dikebumikan,

\footnotetext{
33 Ibid., 117.

34 Ibid.

35 Ibid., 118.

36 'Abd al-Rahman Badawi, al-Falsafah wa al-Falasifah...., 114-115.

37 Salah al-Din Khalil bin Aybak bin 'Abd Allah al-Safadi, al-Wafi bi al-Wafiyyat (Beirut: Dar Ihya' al-Turath: 2000), vol. 2, 82.
} 
sementara, di Jabanah, dan tiga bulan kemudian, dibawa ke Cordoba, untuk dikebumikan di dekat makam leluhurnya, di komplek makam Ibnu 'Abbas RA. ${ }^{38}$

\section{Konsep Pendidikan Fiqih Menurut Ibnu Rusyd}

Pendidikan adalah upaya mempersiapkan individu, dari sisi jasmani, akal, atau rohani, yang dilakukan secara bertahap, sejak usia dini, sampai senja, untuk kehidupan yang lebih baik, kemudian fiqih adalah mengetahui, dan memahami hukum Islam, beserta dalil-dalilnya, secara terperinci. Maka pendidikan fiqih adalah upaya mempersiapkan individu, untuk mengetahui, dan memahami hukum Islam, beserta dalil-dalilnya, secara terperinci. Kemudian, jika berpijak pada pendapatnya al-'Amidi, bahwa fiqih adalah hukum Islam, maka bisa diambil pengertian bahwa pendidikan fiqih adalah pendidikan hukum Islam.

Pendidikan bisa dipahami sebagai perbuatan ('amal), dan bisa juga dipahami sebagai pengetahuan ('ilm). Maka, pendidikan fiqih bisa berarti 'upaya', dan bisa juga diartikan pengetahuan, tentang bagaimana melaksanakannya. Ketika mengartikan pendidikan fiqih, sebagai 'upaya', maka upaya itu bisa dilakukan oleh seseorang, terhadap dirinya sendiri, atau orang lain. Upaya, yang dilakukan, terhadap diri sendiri disebut belajar, sedang upaya, terhadap orang lain, disebut mengajar/ mendidik. Dan jika mengartikan pendidikan fiqih, sebagai pengetahuan, maka pendidikan fiqih adalah pengetahuan, tentang cara mempersiapkan individu, untuk mengetahui, dan memahami hukum Islam, beserta dalil-dalilnya secara terperinci.

Ibnu Rusyd tidak mengemukakan, tentang Konsep pendidikan fiqih, secara langsung. Namun konsep-konsep tersebut bisa ditemukan, dengan mendalami pemikiran-pemikiran filsafat, yang dikemukakan Ibnu Rusyd.

Menurut Ibnu Rusyd, filsafat adalah mempelajari, dan merenungi segala sesuatu, yang ada (mawjud), sehingga akhirnya, pengetahuan terhadap mawjud itu mengantarkan seseorang kepada pengetahuan, tentang adanya pencipta, yakni dari segi bahwa semua mawjud ini adalah ciptaanNya. Karena sesungguhnya mawjud menjadi petunjuk akan adanya sang pencipta, sehingga pengetahuan terhadap ciptaanNya, menjadi petunjuk akan adanya sang pencipta. Maka semakin sempurna pengetahuan seseorang,

\footnotetext{
38 'Abd al-Rahman Badawi, al-Falsafah wa al-Falasifah...., 115.
} 
tentang yang ada (mawjud), semakin sempurna pula pengetahuannya tentang pencipta. ${ }^{39}$

Dari definisi filsafat, yang dikemukakan oleh Ibnu Rusyd di atas, bisa diambil pemahaman, bahwa filsafat adalah mempelajari, dan merenungi mawjudat, dan pengetahuan ini mengantarkan seseorang, kepada pengetahuan, tentang adanya pencipta mawjudat. Kemudian, dari definisi tersebut, terdapat tiga unsur pokok, sebagai kata kunci, yaitu: logika (mempelajari, dan merenungi), fisika (mawjud), dan metafisika (pencipta mawjudat).

Maka apabila filsafat dikaitkan, dengan hukum Islam, berarti filsafat adalah mempelajari, dan merenungi hukum Islam, sebagai salah satu dari, yang ada (mawjud), sehingga akhirnya, pengetahuan, terhadap hukum Islam itu mengantarkan seseorang kepada pengetahuan, tentang Allah. Semakin sempurna pengetahuan seseorang, tentang yang ada (mawjud), semakin sempurna pula pengetahuannya tentang Allah.

Di dalam kitabnya, Ibnu Rusyd menyatakan, bahwa, pada dasarnya, maksud dari shari'ah adalah mendidik manusia, melalui ajaran, tentang kebenaran, yaitu pengetahuan, yang benar (al-ilm al-haqq), dan perbuatan, yang benar (al-'amal al-haqq). Pengetahuan, yang benar adalah mengetahui Allah swt., dan segala hal, yang wujud, sesuai, dengan kenyataannya, terutama wujud, yang mulia, diantara wujud-wujud tersebut, serta mengenal kebahagiaan, dan kesengsaraan, di akhirat. Sedangkan perbuatan, yang benar, adalah mengerjakan perbuatan-perbuatan, yang bisa mendatangkan kebahagiaan, dan menjauhi perbuatan-perbuatan, yang bisa menyebabkan kesengsaraan..$^{40}$

Ibnu Rusyd menilai, bahwa shari'ah, sebagai sumber hukum Islam, mengandung dua ajaran, yaitu ajaran yang bersifat teoretis ('ilm), dan ajaran, yang bersifat praktis ('amal). Di dalam ajaran teoretis, shari'ah membahas, tentang tuhan, sebagai wujud mutlak, serta persoalan, seperti kebahagiaan, dan kesengsaraan akhirat. Tujuan ajaran, yang bersifat teoretis adalah, untuk menumbuhkan keyakinan mendalam, pada diri manusia, akan wujud mutlak, dan unsur-unsur lainnya, yang berkaitan dengannya. Adapun dalam ajaran praktis, shari'ah menganjurkan manusia, untuk mengerjakan perbuatan-perbuatan, yang bisa membawanya, ke arah kebahagiaan, dan menjauhi kesengsaraan. Ajaran praktis tersebut, harus dipandu dengan ajaran, yang benar, secara teoretis

\footnotetext{
${ }^{39}$ Ibnu Rushd al-Hafid, Fasl al-Maqal...., 22.

40 Ibid., 55.
} 
(ilmu 'amali), sehingga amal praktis senantiasa sesuai dengan amal teoretisnya.

Di dalam pembahasan ilmu 'amali, perbuatan ('amal) itu terbagi dua, yaitu perbuatan, yang dilakukan oleh anggota badan, secara lahir (af'al dahirah badaniyyah), dan perbuatan, yang dilakukan oleh hati (af'al al-qulub), seperti syukur, sabar, dan sebagainya. Ilmu tentang perbuatan, yang dilakukan oleh anggota badan, secara lahir, disebut fiqih, dan perbuatan, yang dilakukan oleh hati, disebut zuhud, atau juga ilmu akhirat. ${ }^{41}$ Dengan demikian, tujuan pendidikan fiqih, sejatinya adalah mengajarkan manusia, untuk melakukan perbuatan, yang benar.

Orang bahagia adalah orang yang telah meraih kesempurnaan, yang diinginkan, dimana hal tersebut dibangun, atas pengetahuan, yang benar, dan selanjutnya, pengetahuan tersebut diamalkan, dengan baik. Berdasarkan hal ini pula, alQuran mengisyaratkan instrumen dalam memperoleh pengetahuan sebagaimana firman Allah SWT:

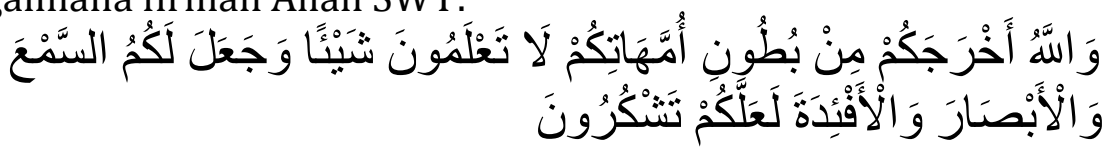

"Dan Allah mengeluarkanmu dari perut ibumu dalam keadaan tidak mengetahui sesuatu pun, dan Dia memberi kamu pendengaran, penglihatan, dan hati, agar kamu bersyukur."42

Bisa dikatakan Quran adalah kitab pengetahuan, yang diturunkan, kepada manusia, untuk memberikan petunjuk, kepada manusia. Manusia lah, yang harus berpikir, dan menemukan petunjuk, sehingga manusia berjalan, di atas jalan kebenaran. Jika persepsi manusia tidak berjalan, maka matanya tidak bisa menyaksikan cahaya hidayah. Jelas, selama manusia tidak menggunakan, dengan baik, potensi, yang Tuhan berikan kepadanya, maka tentunya, harga dirinya lebih rendah, dari binatang, sebagaimana firman Allah swt.:

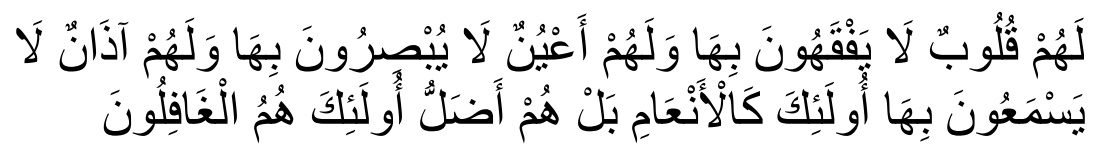

"Mereka mempunyai hati, tetapi mereka tidak mempergunakannya, untuk memahami (ayat-ayat Allah), mereka mempunyai mata, (tetapi) mereka tidak mempergunakannya, untuk melihat (tanda-

\footnotetext{
${ }^{41}$ Ibnu Rushd al-Hafid, Fasl al-Maqal..., 56.

${ }^{42}$ QS. Al-Nahl : 78
} 
tanda kekuasaan Allah), dan mereka mempunyai telinga, (tetapi) mereka tidak mempergunakannya, untuk mendengar (ayat-ayat Allah). Mereka itu seperti binatang ternak, bahkan mereka lebih sesat lagi. Mereka itulah orang-orang, yang lalai." 43

Secara metodologis, menurut Ibnu Rusyd, ilmu filsafat terdiri dari dua bagian, yaitu konsep (tasawwur) dan pembuktian (tasdiq). Antara tasawwur, dengan tasdiq saling terkait, satu sama lain, sehingga tanpa adanya yang salah satu, status ilmunya menjadi salah. Sejatinya, setiap pembuktian, selalu, didahului oleh dua konsep. Tanpa didahului oleh dua konsep, maka seseorang tidak akan benar, dalam mengetahui sesuatu. Misalnya, jika seseorang tidak memahami konsep, tentang 'alam' dan 'baru', maka dia tidak akan dapat menggambarkan adanya pembuktian, bahwa alam itu baru. 44

Sebagaimana filsafat, shari'at juga mengajarkan dua bagian keilmuan, yaitu konsep (tasawwur), dan pembuktian (tasdiq). Terdapat dua metode, yang berkaitan, dengan konsep, yaitu (1) sesuatu, yang menunjuk pada dirinya sendiri, dan (2) sesuatu, yang menyerupainya (simbol). Adapun berkaitan, dengan pembuktian (tasdiq), terdapat tiga metode pembuktian kebenaran, yaitu (1) retoris (Khitabiyyah), (2) dialektik (Jadaliyyah), dan demonstratif (burhaniyyah). ${ }^{45}$ Ketiga metode pembuktian kebenaran tersebut, disesuaikan, dengan tingkat kesiapan pemikiran manusia, sebagai subjek pendidikan.

\section{Kontribusi Ibnu Rusyd Terhadap Perkembangan Fiqih}

Sejak persebaran Islam, ke berbagai penjuru bumi, pada masa al-khulafa' al-rashidin, muncul pusat-pusat perkembangan ilmiah, di negeri-negeri, yang dikuasai, oleh Islam seperti Mekah, Madinah, Kufah, Basrah, Syam, Mesir, dan Yaman. Perkembangan ini terjadi, seiring, dengan menyebarnya para sahabat Nabi, ke berbagai penjuru negeri tersebut, sebagai pemimpin, maupun guru agama, bagi rakyat setempat. Dari pusat-pusat keilmuan Islam, yang ada, menguat dua aliran metodologi, yang belakangan dikenal, sebagai aliran Kufah, atau Ahl al-Ra'yi, dengan pusatnya di Irak, dan aliran Madinah, atau Ahl al-Hadith, dengan pusatnya di Hijaz. Ahl al-Ra'yi

\footnotetext{
${ }^{43}$ QS. Al-a'raf : 179

44 Aksin Wijaya, Teori Interpretasi Ibnu Rushd; Kritik Ideologis-Hermeneutis (Yogyakarta: LKIS, 2009), 120.

45 Ibnu Rushd al-Hafid, Fasl al-Maqal..., 55.
} 
dikenal, sebagai aliran, yang memiliki persyaratan ketat, bagi penerimaan riwayat, dan cenderung mempergunakan pendekatan rasional, dalam memecahkan berbagai persoalan, yang mengemuka. Sementara Ahl al-Hadith dikenal, sebagai aliran, yang sangat mengedepankan dalil-dalil, dari teks suci baik al-Qur'an, maupun al-Sunnah, dalam menjawab persoalan, yang ada. Adapun jika dari riwayat tidak diketemukan petunjuk, mereka cenderung bersikap tawaqquf, atau memilih tidak memberi keputusan definitif terhadapnya. Dalam sejarahnya, antara kedua aliran ini terjadi perdebatan sengit, yang berusaha saling mengunggulkan metodologi keilmuannya masing-masing. ${ }^{46}$

Perbedaan metode, yang digunakan beristinbath hukum, membawa perbedaan pendapat, dikalangan para imam madzhab. Imam Syafi'i dominan menggunakan kias, dan menolak istihsan; Imam Abu Hanifah menggunakan kias, juga istihsan; Imam malik, selain menggunakan kias, dan istihsan, juga menggunakan maslahah mursalah, 'urf, ijma' ahli Madinah, saddudzzari'ah, dan istishab; sedangkan Imam Hanbali menggunakan kias, sadduddzari'ah, dan hadits mursal. ${ }^{47}$

Setelah periode ijtihad, yang membanggakan umat Islam, di masa tabi'in, dan para imam madzhab, ijtihad mengalami kemunduran, akibatnya, fiqih Islam pun menjadi mundur, dan lamban, bahkan, dapat dikatakan bahwa ijtihad pada masa ini menjadi beku. Semangat ijtihad para mujtahid, lambat laun, menjadi lesu, kualitas dan kuntitasnya pun semakin berkurang. Dalam memecahkan masalah fiqih, umumnya, para mujtahid enggan mengistinbath hukum, dengan secara langsung merujuk, kepada al-Qur'an dan al-Sunnah, melalui beberapa metode ijtihad, seperti yang dilakukan, oleh para mujtahid, pendahulu mereka. Mereka cenderung mencari, dan menerapkan produk-produk hukum, hasil ijtihad para mujtahid sebelumnya, walaupun sebagian, dari hasil ijtihad mereka, mungkin sudah kurang, atau sudah tidak sesuai lagi untuk memecahkan masalah-masalah, yang dihadapi ketika itu. Lebih dari itu, sikap toleransi bermadzhab semakin menipis, di kalangan sesama pengikut madzhab fiqih, yang ada, bahkan acap kali timbul persaingan, dan permusuhan, sebagai akibat, dari sikap fanatisme madzhab, yang berlebihan. ${ }^{48} \mathrm{Hal}$ ini terus berlangsung, sampai di masa hidupnya Ibnu Rusyd.

\footnotetext{
46 Huzaemah Tahido Yanggo, Pengantar Perbandingan Mazhab (Jakarta: Logos, 1997), 33.

47 Ibid., 37.

${ }^{48}$ Ibid., 39.
} 


\section{Fiqih Di Masa Ibnu Rusyd}

Cordoba (Cordova), Andalusia, Spanyol Selatan, adalah tanah kelahiran Ibn Rusyd. Cordoba adalah salah satu provinsi Andalusia, yang terletak di sebelah Sungai Guadalquivir. Kota ini didirikan, oleh Claudius Marcellus, dengan nama Corduba, pada zaman Romawi Kuno. Pada masa kekuasaan Islam, orang Arab menyebutnya Qurthubah. Cordoba dibangun sebagai ibukota Dinasti Umayah Spanyol oleh Abdurrahman al-Dakhil. Puncak kejayaan dinasti Islam Eropa ini dicapai pada periode pemerintahan Abdurrahman al-Nashir (929-961 M), dan al-Hakam (961-976 M), yang ditandai dengan kemajuan di segala bidang.

Andalusia memiliki banyak pusat keilmuan, mulai dari Madrasah Cordoba, Sevilla, Almeria, Toledo, hingga Zaragoza. Ilmu bahasa, dan ilmu-ilmu agama menyebar secara merata di kota-kota tersebut. Namun, masing-masing madrasah memiliki karakteristik yang menonjol di bidang keilmuan lain. Toledo dan Zaragoza lebih dominasi oleh matematika, astronomi, filsafat metafisika, dan kedokteran. Di Toledo terdapat astronomer terkemuka bernama al-Zarqali (Latin: Arzachel) dan matematikawan bernama alBaghunsyi. Tak kalah dengan Toledo, Zaragoza memiliki Ibn Bajjah (Latin: Avempace) yang terkenal dalam bidang astromoni, logika, musik, filsafat, psikologi, dan sastra. Sedangkan Almeria merupakan central, bagi gerakan gnostik di Andalusia, dimana ordo-ordo mistik berkembang di bawah bimbingan master sufi Ibn al-'Arif, penerus madrasah tarekat Ibn Masarah al-Qurthubi. ${ }^{49}$

Diantara kelima madrasah tersebut, Madrasah Cordoba dan Sevilla adalah yang paling berpengaruh. Sevilla adalah ibukota lama, dan Cordoba adalah ibukota baru. Persaingan antar keduanya tidak hanya dalam ranah politik, melainkan menjalar pada persaingan kebudayaan. Cordoba dan Sevilla memiliki pakar-pakar, dalam segala bidang, tetapi masing-masing kota memiliki keunggulan, dalam bidang tertentu. Cordoba lebih menonjol dalam bidang pemikiran teoretis, sedangkan Sevilla menonjol dalam seni, dan sastra. Hal ini diungkapkan sendiri oleh Ibn Rusyd kepada koleganya yang bernama Ibn Zahr (Latin: Avenzoar), "Jika ada orang alim meninggal dunia dan kitab-kitabnya akan dijual maka kitab-kitab tersebut dibawa ke Cordoba. Jika ada musisi yang

49 'Abid al-Jabiri, al-Turath wa al-Hadathah, (Kairo: Markaz Diarasah al-Wahdah al-Arabiyah, 2006), 179-180. 
meninggal kemudian alat musiknya akan dijual maka dibawa ke Sevilla".50

Dalam konteks internal, Cordoba adalah ibukota sekaligus pusat kebudayaan intelektual, yang paling menonjol di Andalusia. Di sisi lain, dalam konteks eksternal dunia Islam, Cordoba terlibat dalam rivalitas dengan Dinasti Abasiyah di Baghdad dan Dinasti Fatimiyah di Cairo. Rivalitas ketiga dinasti tersebut tidak hanya terbatas, dalam persoalan politik belaka, tetapi menjalar, dalam bidang epistemologi. Dinasti Abasiyah mengusung corak teologi Mu'tazilah-Asy'ariyah, dan madzhab fiqih Hanafiyah, sedangkan di pihak lain, Dinasti Fatimiyah mengusung fiqih Syiah, dan filsafat Bathiniyah. Dinasti Abasiyah bersenjatakan epistemologi bayani (retoris) vis a vis Dinasti Fatimiyah yang bersenjatakan epistemologi irfani (gnostik). Untuk menguatkan ideology, dan epistemologi masing-masing, Dinasti Abasiyah mendapuk logika Aristoteles (mantiq), manakala Dinasti Fatimiyah mendapuk filsafat esoterik Hermetisisme. Rivalitas politik, dan kebudayaan dua dinasti tersebut mengambarkan betapa kentalnya fanatisme sektarianistik Sunni Abasyiah dan Syiah Fatimiyah.

Di tengah-tengah rivalitas dua dinasti tersebut, Cordobasebagai kota paling representatif Andalusia-menyadari adanya tantangan untuk mendefinisikan identitas kulturalnya, yang khas. Cordoba dituntut untuk mencanangkan "proyek kebudayaan baru" (al-masyru' al-tsaqafi al-jadid) dalam rangka pencarian jati diri, dan mempertahankan eksistensinya, dari serangan kebudayaan Dinasti Abasiyah dan Fatimiyah. Dalam bidang fiqih, Cordoba dan wilayah Andalusia lainnya diwarnai, oleh corak orisinalitas fiqih, yang selaras, dengan fiqih para sahabat, dan tabiin, sejak penaklukan Islam pada tahun $92 \mathrm{H}$. Dinasti Umawiyah Andalusia, awalnya, menganut madzhab al-Auza'I, yang diikuti oleh Bani Umayah di Damaskus. Madzhab Auza'i dinilai selaras, dengan madzhab sahabat, dan tabiin, yang menaklukan Andalusia, yakni sama-sama bertumpu pada riwayat.

Pada periode berikutnya, Dinasti Umayah Andalusia mengetahui sikap politik Imam Malik, pendiri madzhab Malikiyah, yang lebih mendukung Dinasti Umawiyah, ketimbang kebijakankebijakan politik Dinasti Abasiyah. Melihat adanya keuntungan secara politis, Dinasti Umayah berinisiatif mengadopsi madzhab Malikiyah, yang juga bertumpu pada riwayat sebagaimana madzhab Auza'i, sebagai madzhab resmi imperium Andalusia.

50 Abid al-Jabiri, Ibn Rusyd; Sirah wa Fikr, (Kairo: Markaz Diarasah al-Wahdah alArabiyah, 1998), 13. 
Peresmian madzhab Malikiyah di Andalusia, tak lain merupakan wujud implementasi, dari proyek kebudayaan, sekaligus manuver politik, yang dicanangkan, guna menandingi hegemoni kebudayaan Abbasiyah, dan Fatimiyah. Di sisi lain, dalam bidang filsafat, mulamula Cordoba adalah kota, yang steril dari filsafat Yunani. Namun, menyadari semakin ketatnya persaingan, dengan kebudayaan Abasiyah, dan Fatimiyah, Khalifah Abdurrahman al-Nashir dan alHakam al-Muntasir Billah bertekat mengumpulkan khazanah keilmuan filsafat, dan pelbagai disiplin ilmu lainnya, dari Baghdad, Mesir, dan kawasan Timur Islam lainnya. Inilah puncak kejayaan intelektual Dinasti Umawiyah Andalusia. ${ }^{51}$

Sayangnya, kejayaan tersebut tidak berlangsung lama, sebab pada tahun 1009 M Andalusia mengalami keruntuhan, dan memasuki era muluk al-thawaif, masa perpecahan, dan munculnya kerajaan-kerajaan kecil. Pada tahun $1086 \mathrm{M}$, perpecahan ini dapat disatukan kembali, seiring dengan munculnya kekuasaan Dinasti Murabithin, di Andalusia. Yang mengecewakan, Dinasti Murabithin justru lebih didominasi, oleh kelompok agamawan penganut madzhab Maliki, yang sangat konservatif. Hegemoni Malikiyah memang telah berlangsung lama sejak ditetapkan sebagai madzhab resmi Dinasti Umawiyah. Namun, hegemoni ini bermetamosfosis, menjadi konservatisme radikal pada masa Murabithin. Ironisnya, konservatisme ini mendapatkan legitimasi dari Ali bin Yusuf bin Tasyfin, Amir Dinasti Murabithin. Untuk mengilustrasikan fenomena ini, al-Marakishi dalam menulis,

Tidak ada ulama, yang bisa mendapatkan tempat di pemerintahan kecuali orang-orang, yang membidangi fiqih madzhab Maliki. Pada masa itu, kitab fiqih Malikiyah disebarluaskan, dan masyarakat diwajibkan mengamalkannya. Kitab-kitab selain Malikiyah disingkirkan".52

Stagnansi pemikiran Andalusia era Murabithin memang memprihatinkan. Kitab Ihya' Ulum al-Din karya al-Ghazali pun tidak selamat, dari pembakaran massal ini. Yang lebih mengerikan, ulama fiqih, pada saat itu, mengeluarkan fatwa mati, bagi siapa pun yang menyimpan karya-karya al-Ghazali. ${ }^{53}$ Konservatisme tersebut otomatis memantik perlawanan, dari kalangan oposisi. Pada tahun $1152 \mathrm{M}$, muncullah revolusi kaum oposisi, yang menyerukan

${ }^{51}$ Abid al-Jabiri, al-Turats wa al-Hadatsah...., 180-184.

${ }^{52}$ Al-Marakisyi, al-Mu'jab fi Talkhish Akhbar al-Maghrib (Kairo: Mathba' Istiqamah, 1949), 88.

${ }^{53}$ Hamadi Ubaydi, Ibn Rushd wa Ulum al-Syariah (Beirut: Dar al-Fikr al-'Arabi, 1991), 179. 
pembaharuan pemikiran, yang dipimpin oleh Ibn Tumart. Ibn Tumart adalah cendekiawan tercerahkan, yang pernah berguru pada al-Ghazali, Abi Bakar al-Syasyi, dan Ibn Abd al-Jabbar di Baghdad, Abi Bakar al-Tharthusyi di Mesir, dan Ibn Hamdin di Cordoba. Dengan tekat mewujudkan perubahan sosial keagamaan, gerakan oposisi berhasil menumbangkan Dinasti Murabithin dan mendirikan Dinasti Muwahidin. ${ }^{54}$

Sebelum Bidayat al-Mujtahid ditulis, sebagai seorang cerdikcendekia Ibn Rusyd menyadari betul dinamika intelektual, pada masanya, yang didominasi oleh kemandegan pemikiran (stagnansi). ${ }^{55}$ Stagnansi umat Islam sangatlah akut, hingga revolusi Ibn Tumart pun tak sepenuhnya mampu membendung. Stagnansi ini diperparah, atau mungkin diakibatkan, oleh mengendurnya kekuatan politik dinasti-dinasti Islam. Abasyiah melemah seiring munculnya hegemoni Saljukiyah, dan Buwaihiyah. Fatimiyah terpecah belah akibat konflik internal, sedangkan Andalusia tidak seutuhnya bersatu, pasca era perpecahan muluk al-thawaif. Melemahnya kekuasaan sebuah pemerintahan sama artinya, dengan melemahnya dukungan penguasa terhadap kreativitas para ulama. ${ }^{56}$

Era stagnansi ini ditandai, dengan munculnya asumsi-asumsi dogmatis, bahwa capaian para fuqaha klasik telah sempurna, sehingga tidak butuh pembaharuan pemikiran. Asumsi ini kemudian menjadi jargon kaum pembebek (muqallidin) yang digubah dalam syair, "wa kullu khairin fi ittiba'i man salaf wa kullu syarrin fi ittiba'i man khalaf". ${ }^{57}$ Syair ini menyatakan bahwa "kebaikan hanya ada, dalam sikap membebek, pada para pendahulu, dan kejelekan ada, dalam sikap membebek, pada generasi belakangan". Generasi pendahulu (salaf) dianggap, sebagai pemegang kebaikan, dan kebenaran, sementara generasi belakangan (khalaf) sebagai penyebab keburukan, dan kesesatan.

\footnotetext{
54 'Atif al-Iraqi, Ibn Rusyd Mufakkir al-Arabi wa Raid al-Tanwir (Cairo: Majlis A'la li al-Tsaqafah, 1993), 199-200.

55 Banyak versi dalam mengidentifikasi masa awal munculnya stagnansi. T. J. De Boer, dalam The History of Philosophy in Islam, menilai stagnansi muncul setelah runtuhnya Baghdad di tangan Mongol. Menurut al-Saukani, sejak tahun 140 H. Menurut Ibn Qayyim al-Jauziyyah dan Ibn Hazm, sejak abad ke-4 H. (Yahya Muhammed, al-Ijtihad wa Taqlîd wa al-Itba' wa al-Nadhr (Beirut: Dar al-Intishar al-Arabi, 2000), 91.

${ }^{56}$ Hamadi Ubaydi, Ibn Rusyd wa 'Ulum..., hlm.157.

57 Hasan bin 'Umar al-Sinawani, al-Asl al-Jami' li Idhah al-Durar al-Mandumah (Tunisia: Matma'ah al-Nahdah, 1928), vol. 2, 108.
} 
Inilah logika kaum konservatif era skolastik, yang terlalu mensakralkan para pendahulu (taqdis al-salaf).

Banyak faktor, yang menyebabkan stagnansi, antara lain: pertama, ditutupnya pintu ijtihad, oleh ulama konservatif, yang berimbas pada pemasungan kebebasan intelektual; kedua, kodifikasi pendapat-pendapat ulama klasik, pada masa Abbasiyyah. Pasca kodifikasi, generasi sesudahnya merasa cukup, pada produkproduk hukum lama, dengan cara merujuknya. Dengan demikian menjadi minim dorongan untuk berinovasi; ketiga, fanatisme bermadzhab, yang mengakibatkan keterjebakan para ulama dalam pembelaan terhadap madzhab masing-masing. Konsekuensinya, aktivitas intelektual hanya dikerangkakan untuk membenarkan madzhabnya sendiri dan menyalahkan madzhab lain. ${ }^{58}$ Oleh sebab itu, pada era ini banyak kajian yang tidak obyektif. ${ }^{59}$ Produk intelektual kalangan ini dicirikan oleh ketundukan pada pendahulu tanpa kritisisme. Para pendahulu terlalu dikuduskan, sehingga yang terjadi adalah semacam sikap "pemberhalaan" terhadap kitab-kitab fiqih karya pendahulu. Untuk mendeskripsikan fenomena stagnansi pada masanya, Ibn Rusyd berkata, "Di sini ada golongan orang awam dan fuqaha. Golongan awam adalah pembebek. Perbedaan mereka dengan fuqaha adalah bahwa fuqaha menghapalkan pendapat-pendapat para mujtahid kemudian mengabarkan kepada orang awam. Jadi tingkatan fuqaha hanyalah penukil. Fuqaha kadang keterlaluan menganalogikan problematika baru, yang tidak ditemukan dalam kitab-kitab induk, dengan pendapat-pendapat para mujtahid. Dengan demikian, mereka telah

58 Muhammad al-Hudhari Bik, Tarikh al-Tashri' al-Islami (Jeddah: al-Haramayn, t.t.), 325.

59 Contohnya, al-Jassas mengarang tafsir Ahkam al-Qur'an untuk membela madhhab Hanafiyyah. Ilkiya' al-Hirasi al-Shafi'i, fanatikus Syafi'iyyah, mengarang Ahkam al-Qur'an untuk men-counter terhadap, dan membela madzhabnya dari, serangan pedas al-Jassas. Syihab al-Din Abu al-Abbas Ahmad bin Yusuf bin Muhammad al-Halbi mengarang al-Qawl al-Wajîz fi Ahkam alQur'an, untuk membela mati-matian madzhab Syafi'iyyah. Abu Bakar bin al'Arabi mengarang Ahkam al-Qur'an untuk membentengi madzhab Malikiyah. Miqdad al-Sayuri menulis Kanz al-Irfan fi Fiqh al-Qur'an untuk membela Syi'ah Itsna 'Asyariyyah. Sedangkan al-Thamrat al-Yani'ah wa al-Ahkam al-Wadhihah al-Qathi'ah karya Yusuf al-Sulasi untuk membela Syi'ah Zaydiyyah. Beberapa tafsir bercorak fikih ini menjadi bukti bahwa mereka menafsirkan al-Quran tidak secara objektif, melainkan secara subjektif, untuk kepentingan kelompok masing-masing. Husayn al-Dzahabi, al-Tafsir wa al-Mufassirun (Kairo: Dar alHadith, 2005), vol. 2, 381-414). 
memposisikan pendapat pendahulu sebagai sumber hukum (ashal). Ini adalah bid'ah dan kesesatan".60

Menyaksikan fenomena tersebut, Ibn Rusyd merasa prihatin, dan segera meresponnya, dengan menulis karya Bidayat alMujtahid wa Nihayat al-Muqtashid, sejak tahun 564, hingga $565 \mathrm{H}$, kecuali bab Haji, yang selesai ditulis dua puluh tahun kemudian, tepatnya pada hari Rabu, 9 Jumadil Ula, 584 H/1188 M. ${ }^{61}$ Karya ini diproyeksikan, untuk mendobrak kemapanan, mengkritik ortodoksi fuqaha, dan menggerakkan kejumudan fiqih, dengan cara membuka pintu ijtihad. Untuk memperjelas tujuan penulisan karyanya, Ibn Rusyd menulis, "Tujuanku dalam kitab ini adalah menjelaskan masalah-masalah yang disepakati dan atau diperdebatkan oleh fuqaha dengan menguraikan rahasia-rahasia perdebatan itu secara metodologis".62 "Kitab ini aku tulis agar seorang peminat fiqih mencapai tingkatan mujtahid". ${ }^{63}$

\section{Fiqih Pasca Ibnu Rusyd}

Dalam perkembangan selanjutnya, khususnya di zaman modern, ulama fiqih mempunyai kecenderungan kuat, untuk melihat berbagai pendapat, dari berbagai mazhab fiqih, sebagai satu kesatuan, yang tidak dipisahkan. Dengan demikian, ketegangan antar pengikut mazhab mulai mereda, khususnya, setelah Ibnu Taimiyah, dan Ibnu Qayyim al-Jauziah mencanangkan, bahwa pintu ijtihad tidak pernah tertutup. Suara vokal Ibnu Taimiyah dan Ibnu Qayyim al-Jauziah ini kemudian dilanjutkan oleh Muhammad bin Abdul Wahhab (1115 H./1703 M.-1201 H./1787 M.; pendiri aliran Wahabi di Semenanjung Arabia) dan Muhammad bin Ali asy-Syaukani. Menurut Ibnu Qayyim al-Jauziah, bermazhab merupakan perbuatan bid'ah, yang harus dihindari, dan tidak satu orang pun, dari imam yang empat (Imam Abu Hanifah, Imam Malik, Imam asy-Syafi 'i, dan Imam Ahmad bin Hanbali membolehkannya). Sejak saat itu, kajian fiqih tidak lagi terikat, pada salah satu mazhab, tetapi telah mengambil bentuk kajian komparatif, dari berbagai mazhab, yang dikenal dengan istilah fiqih muqaran.

Sekalipun studi komparatif telah dijumpai, sejak zaman klasik seperti yang dijumpai, dalam kitab fiqih al-Umm karya Imam asy-

\footnotetext{
60 Ibn Rusyd al-Hafid, al-Dharuri fi Ushul al-Fiqh (Beirut: Dar al-Gharb, 1994), 125.

61 Ibnu Rushd al-Hafid, Bidayat al-Mujtahid...., vol. 2, 142.

62 Ibid., vol. 1, 9.

63 Ibid., vol. 3, 210.
} 
Syafi'i, al-Mabsut karya as-Sarakhsi, al-Furuq karya Imam al-Qarafi (w. 684 H./1285 M.), dan al-Mugni karya Ibnu Qudamah (tokoh fiqih Hanbali), sifat perbandingan, yang mereka kemukakan tidak utuh, dan tidak komprehensif, bahkan tidak seimbang, sama sekali. Di zaman modern, fiqih muqaran dibahas ulama fiqih, secara komprehensif, dan utuh, dengan mengemukakan inti perbedaan, pendapat, dan argumentasi (baik dari nash maupun rasio), serta kelebihan, dan kelemahan masing-masing mazhab, sehingga pembaca (khususnya masyarakat awam), dengan mudah dapat memilih pendapat, yang akan diambil. Pada zaman modern, suara yang menginginkan kebangkitan fiqih, kembali semakin vokal, khususnya setelah ulama fiqih, dan ulama bidang ilmu lainnya menyadari ketertinggalan dunia Islam, dari dunia Barat. Bahkan banyak diantara sarjana muslim yang melakukan studi komparatif antara fiqih Islam, dan hukum produk Barat.

\section{Penutup}

pada dasarnya, maksud dari shari'ah adalah mendidik manusia, melalui ajaran, tentang kebenaran, yaitu pengetahuan, yang benar (al-ilm al-haqq), dan perbuatan, yang benar (al-'amal al-haqq). Pengetahuan, yang benar adalah mengetahui Allah swt., dan segala hal, yang wujud, sesuai, dengan kenyataannya, terutama wujud, yang mulia, diantara wujud-wujud tersebut, serta mengenal kebahagiaan, dan kesengsaraan, di akhirat. Sedangkan perbuatan, yang benar, adalah mengerjakan perbuatan-perbuatan, yang bisa mendatangkan kebahagiaan, dan menjauhi perbuatan-perbuatan, yang bisa menyebabkan kesengsaraan.

Ibnu Rusyd menilai, bahwa shari'ah, sebagai sumber hukum Islam, mengandung dua ajaran, yaitu ajaran yang bersifat teoretis ('ilm), dan ajaran, yang bersifat praktis ('amal). Di dalam ajaran teoretis, shari'ah membahas, tentang tuhan, sebagai wujud mutlak, serta persoalan, seperti kebahagiaan, dan kesengsaraan akhirat. Tujuan ajaran, yang bersifat teoretis adalah, untuk menumbuhkan keyakinan mendalam, pada diri manusia, akan wujud mutlak, dan unsur-unsur lainnya, yang berkaitan dengannya. Adapun dalam ajaran praktis, shari'ah menganjurkan manusia, untuk mengerjakan perbuatan-perbuatan, yang bisa membawanya, ke arah kebahagiaan, dan menjauhi kesengsaraan. Ajaran praktis tersebut, harus dipandu dengan ajaran, yang benar, secara teoretis (ilmu 'amali), sehingga amal praktis senantiasa sesuai dengan amal teoretisnya. 


\section{DAFTAR PUSTAKA}

Abu Zayd, Bakr bin 'Abd Allah al-Madkhal al-Mufassal li Madhhab al-Imam Ahmad wa Takhrijat al-Ashab (Jiddah: Dar al'Asimah, 1417 H.)

al-Amidi, 'Ali bin Abi 'Ali, al-Ihkam fi Usul al-Ahkam (Bairut: alMaktab al-Islami, tt.)

al-Ansari, Muhammad bin Mukarram bin 'Ali Lisan al-'Arab (Bairut: Dar Sadir, 1414 H.)

al-'Aqqad, Abbas Mahmud, Ibn Rusyd (Mesir: Dar al-Ma'arif, tt.)

al-Dimashqi, Khayr al-din bin Mahmud al-Zarkali, al-A'lam li alZarkali (Damaskus: Dar al-'Ilm li al-Malayin, 2002)

al-Dhahabi, Shamsh al-Din Abu Abd Allah Muhammad bin Ahmad, Tarikh al-Islam wa Wafiyyat al-Mashahir wa al-A'lam (Bairut: Dar al-Kitab al-'Arabi, 1993)

al-Dzahabi, Husayn, al-Tafsir wa al-Mufassirun (Kairo: Dar alHadith, 2005)

al-Hafid, Ibn Rusyd, al-Dharuri fi Ushul al-Fiqh (Beirut: Dar alGharb, 1994)

al-Iraqi, 'Atif, Ibn Rusyd Mufakkir al-Arabi wa Raid al-Tanwir (Cairo: Majlis A'la li al-Tsaqafah, 1993)

al-Jabiri, 'Abid, al-Turath wa al-Hadathah, (Kairo: Markaz Diarasah al-Wahdah al-Arabiyah, 2006)

al-Jabiri, Abid, Ibn Rusyd; Sirah wa Fikr, (Kairo: Markaz Diarasah alWahdah al-Arabiyah, 1998)

al-Jauziyyah, Ibn al-Qayyim I'lam al-Muwaqqi'in 'An Rabb al-'Alamin (Bairut: Dar al-Kutub al-'Ilmiyyah, 1991)

Al-Marakisyi, al-Mu'jab fi Talkhish Akhbar al-Maghrib (Kairo: Mathba' Istiqamah, 1949)

al-Munyawi, Mahmud bin Muhammad Abu al-Munzir, al-Mu'tasar min Sharh Mukhtasar al-Usul min 'Ilm al-Usul (Mesir: alMaktabah al-Shamilah, 2010)

al-Safadi, Salah al-Din Khalil bin Aybak bin 'Abd Allah, al-Wafi bi alWafiyyat (Beirut: Dar Ihya' al-Turath: 2000)

al-Sinawani, Hasan bin 'Umar, al-Asl al-Jami' li Idhah al-Durar alMandumah (Tunisia: Matma'ah al-Nahdah, 1928)

al-Taftazani, Sa'ad al-Din Mas'ud bin 'Umar, Sharh al-Talwih 'Ala alTawdhih (Mesir: Maktabah Sabih, tt.)

al-Ya'mari, Ibnu Farhun Burhan al-Din, al-Dibaj al-Muhadhdhab fi Ma'rifat A'yan 'Ulama' al-Madhhab (Beirut: Dar al-Kutub alIlmiyyah, tt.) 
al-Zunjani, Shihab al-Din Mahmud bin Ahmad, Takhrij al-Furu' 'ala al-Usul (Bairut: Muassasah al-Risalah, $1398 \mathrm{H}$.)

al-Zarkashi, Badr al-din Muhammad bin Abd Allah, al-Bahr al-Muhit fi Usul al-Fiqh (Bairut: Dar al-Kutub, 1994)

al-Zuhayli, Wahbah, Usul al-Fiqh al-Islami (Damaskus: Dar al-Fikr, 1986)

Bik, Muhammad al-Hudhari, Tarikh al-Tashri' al-Islami (Jeddah: alHaramayn, t.t.)

Dahlan, Abdul Aziz (ed.) et. al., Ensiklopedi Hukum Islam, Vol. 4 (Jakarta: Ichtiar Baru Van Hoeve, 1996)

Harun, Nasrun, Ushul Fiqh (Jakarta: Logos Wacana Ilmu, 1997)

Khallaf, 'Abd al-Wahhab 'Ilm Usul al-Fiqh (Kairo: Maktabah alDa'wah, tt.)

Musa, Muhammad Yusuf al-Madkhal li Dirasat al-Fiqh al-Islami, (Kairo: Dar al-Kutub al-'Araby, 1953)

Munawwir, Ahmad Warson, Kamus al-Munawwir (Yogyakarta: UPBIK PP al-Munawwir, tt.)

Muhammed, Yahya. al-Ijtihad wa Taqlîd wa al-Itba' wa al-Nadhr (Beirut: Dar al-Intishar al-Arabi, 2000)

Sirry, Mun'im A. Sejarah Fikih Islam (Surabaya: Risalah Gusti, 1996) Ubaydi, Hamadi, Ibn Rusyd wa Ulum al-Syariah (Beirut: Dar al-Fikr al-'Arabi, 1991)

Wijaya, Aksin, Teori Interpretasi Ibnu Rusyd; Kritik IdeologisHermeneutis (Yogyakarta: LKIS, 2009)

Wardi, Moh. "Penerapan Nilai Pendidikan Agama Islam Dalam Perubahan Sosial Remaja", TADRIS: Jurnal Pendidikan Islam STAIN Pamekasan Vol. 7 No. 12013.

Yanggo, Huzaemah Tahido. Pengantar Perbandingan Mazhab (Jakarta: Logos, 1997) 